\title{
Author Correction: Biocultural approaches to pollinator conservation
}

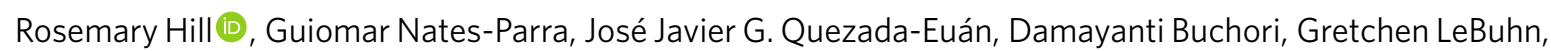
Marcia M. Maués, Petina L. Pert, Peter K Kwapong, Shafqat Saeed, Sara J Breslow, Manuela Carneiro da Cunha, Lynn V. Dicks (D), Leonardo Galetto, Mary Gikungu, Brad G. Howlett, Vera L. Imperatriz-Fonseca, Phil O'B. Lyver,

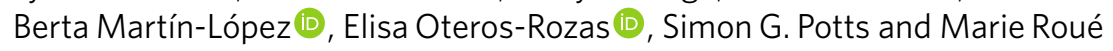

Correction to: Nature Sustainability https://doi.org/10.1038/s41893-019-0244-z, published online 11 March 2019.

In the version of this Analysis originally published, the name of the author Elisa Oteros-Rozas was incorrectly given as 'Elisa Oteros-Roza.' This has now been corrected. 